\title{
Multiple Spinal Cord Melanoma: Case Report with Emphasis on the Difficult Preoperative Diagnosis
}

\author{
Multipl Omurilik Melanomu: Zor Preoperatif Tanmnn Vurgulanmassyla \\ Bir Olgu Sunumu
}

\author{
Xin HUANG, Xinfa PAN, Hongguang HUANG, Renya ZHAN \\ Zhejiang University, College of Medicine, The First Affiliated Hospital, Department of Neurosurgery, Hangzhou, China
}

Correspondence address: Renya ZHAN / E-mail: RenYaZhan@hotmail.com

\begin{abstract}
Primary spinal melanoma (PSM) is rare and usually occurs in the cervical and thoracic regions. Here, we present a case of multiple spinal cord melanoma located at the level of cervical and upper thoracic spine in a 24-year-old male. The patient underwent a T6-T7 thoracic laminectomy and gross-total resection of the duty lesion. The histological findings of the tumor were consistent with an intermediate-grade melanocytoma. To the best of our knowledge, only two cases of multifocal primary melanocytic tumor have been reported in the literature. In this case study we review the pertinent literature and emphasize the importance and difficulties concerning the preoperative diagnosis of multiple PSM.
\end{abstract}

KEYWORDS: Primary spinal melanoma, Intermediate-grade, Multiple, Diagnosis

öz

Primer spinal melanom (PSM) nadirdir ve genellikle servikal ve torasik bölgelerde oluşur. Burada 24 yaşında bir erkekte servikal ve üst torasik omurga seviyesinde oluşmuş bir multipl omurilik melanomu vakasını sunuyoruz. Hastaya T6-T7 torasik laminektomi ve gros total rezeksiyon yapıldı. Tümörün histolojik bulguları orta derece melanositom ile tutarlıydı. Bildiğimiz kadarılla literatürde sadece iki multifokal primer melanostik tümör vakası bildirilmiştir. Bu vaka çalışmasında ilgili literatürü gözden geçirip multipl PSM preoperatif tanısıyla ilgili zorlukları ve tanının önemini vurguluyoruz.

ANAHTAR SÖZCÜKLER: Primer spinal melanom, Orta derece, Multipl, Tanı

\section{INTRODUCTION}

Primary melanocytic tumors of the central nervous system (CNS) consist of a spectrum ranging from well-differentiated melanocytoma to malignant melanoma. PSM was initially reported by Hirschberg in 1906, and accounts for $38 \%$ of all CNS melanomas (9). So far, fewer than 60 cases have been reported in the English literature $(6,13)$. Intermediate-grade melanocytic tumors are not easily classified as melanocytoma or melanoma as they present some histological features associated with aggressive behavior, and moreover, only sporadic cases have been reported in the literature $(2,3)$. To the best of our knowledge, only two cases of multifocal primary melanocytic tumor have been reported in the literature $(1,9)$. In this study, we present a case of multiple spinal cord melanoma located at the level of the cervical and upper thoracic vertebrae, and conduct a review of the pertinent literature.

\section{CASE REPORT}

A 24-year-old male presented with a one-month history of progressive numbness and weakness of the left lower extremity. Physical examination revealed $3 / 5$ muscle strength in the left leg accompanied by impaired sensibility below the level of T-7. Magnetic resonance imaging (MRI) of the thoracic spine revealed intradural, extramedullary, and multifocal ovoid masses located at the level of upper thoracic vertebrae. The largest mass was approximately $1.2 \times 2.0 \mathrm{~cm}$ in size compressing the spinal cord at the T6-7 level. The masses were hyperintense on T1-weighted images, and isointense to hypointense on T2-weighted images. After administration of meglumine gadopentetate, homogeneous enhancement masses and strip enhancement leptomeninges were evident (Figure $1 \mathrm{~A}-\mathrm{C}$ ). The cervical spinal MR imaging indicated the presence of multifocal snatchy lesions at the level of lower cervical vertebra (Figure 2A-C).

The patient underwent a T6-T7 thoracic laminectomy and gross-total resection of the duty lesion. The surgeon observed a dura-based dark brown mass that compressed the edematous spinal cord (Figure 3A,B). Microscopically, highly pigmented spindle-cell lesions with moderate nuclear atypia and regions of necrosis were noted; additionally, the cells exhibited epithelioid and syncytial patterns. The nuclei were uniform and oval with small nucleoli. The lesional cells were immunopositive for $\mathrm{S} 100$ protein and HMB-45, whereas no expression of epithelial membrane antigen was detected (Figure 4A-D). The diagnosis based upon the pathological 

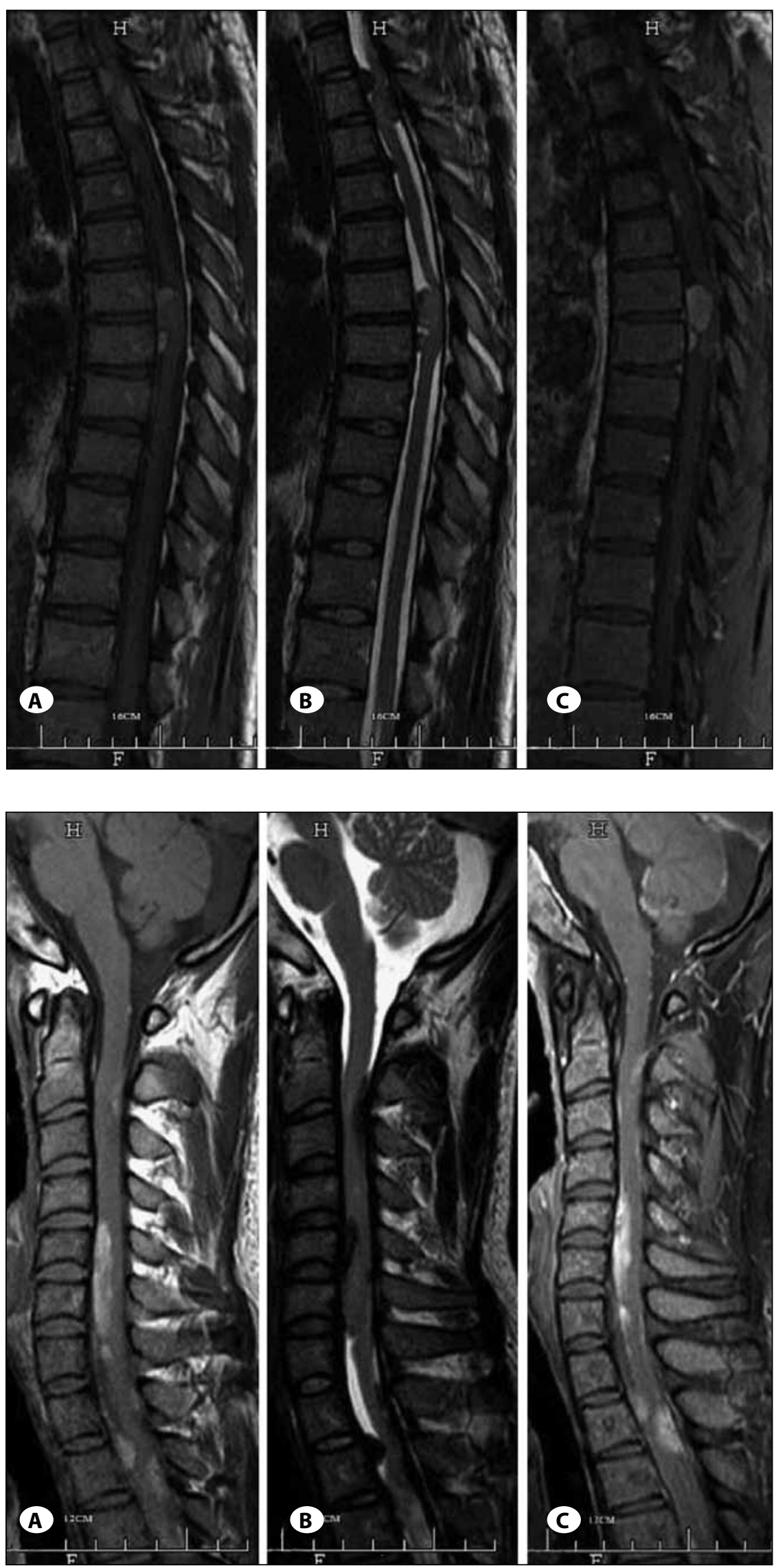

Figure 2: Sagittal MRI of cervical spine shows multifocal snatchy lesions located at the level of lower cervical spine, which has hyperintense signal on T1-weighted images (A), hypointensity on T2-weighted images (B) and noticeable enhancement after the injection of meglumine gadopentetate (C). 
examination was melanoma, suggestive of an intermediategrade melanocytoma.

Postoperatively, left lower-extremity strength and sensibility below the level of T-7 were markedly improved. The MR images of the thoracic spine obtained 1 week after surgery revealed the disappearance of the mass effect at the T6-7 level. A primary lesion was not observed upon subsequent abdominal color Doppler ultrasonography and skin examination, and no intracranial lesions were seen upon MRI of the brain. Therefore, a diagnosis of primary spinal intermediate-grade melanocytoma was made. A second surgery for the additional masses in the lower cervical vertebra and upper thoracic vertebrae was recommended, while the patient chose outpatient follow-up without further treatment.

\section{DISCUSSION}

According to the World Health Organization classification of primary CNS tumors, primary CNS melanoma includes diffuse leptomeningeal melanocytosis or melanomatosis, melanocytoma, and primary malignant melanoma. Primary CNS melanoma is rare, accounting for only $1 \%$ of all melanoma cases, and primary spinal melanoma is even more rare (7). Since first reported by Hirschberg in 1906, approximately 50 to 60 diagnosed cases have been reported in literature $(4,6,13)$. These include melanocytoma, intermediategrade melanocytoma and malignant melanoma. To the best of our knowledge, only two case of multifocal primary melanocytic tumor have been reported in the literature
$(1,9)$. The characteristics of these cases are summarized in Table I. Compared with previously reported cases, the patient presented in this study had a relatively longer lesion, extending from the level of lower cervical vertebra to upper thoracic vertebrae.

The clinical presentation of PSM is non-specific and predominantly consists of symptoms of progressive myelopathy. The slight predilection for the cervical and thoracic spine has been observed as intradural, extramedullary lesions. Currently, MRI is the best method for diagnosing spinal cord tumors. Melanoma characteristically exhibits hyperintesity on T1-weighted images, hypointensity on T2-weighted images, and homogeneous enhancement on $\mathrm{T} 1$ contrast-enhanced images. Melanoma does not always exhibit a homogeneous pattern on MR images and the degree of $\mathrm{T} 1$ and $\mathrm{T} 2$ shortening appears to be directly related to the melanin content (5). Our clinical and neuroimaging findings are similar to the available descriptions.

A preoperative diagnosis of PSM is difficult to achieve. According to the Hayward classification system, a diagnosis of primary melanoma is based on the absence of a melanoma outside the CNS, absence of a melanoma in other CNS sites, and histological confirmation of a melanoma (8). In addition, a number of other CNS lesions may be pigmented and produce melanin, including schwannoma, medulloblastoma, neurofibroma, meningioma, astrocytoma and pituitary tumours. Immunohistochemical and ultrastructural criteria can help differentiate between these entities, because primary

Table I: Summary of Reported Cases of Multifocal Primary Melanocytic Tumor of the Central Nervous System

\begin{tabular}{|c|c|c|c|c|c|c|}
\hline Reference & $\begin{array}{l}\text { Age (yrs), } \\
\text { Sex }\end{array}$ & Location & Pathology & Treatment & $\begin{array}{l}\text { Adjuvant } \\
\text { Therapy }\end{array}$ & Outcome \\
\hline $\begin{array}{l}\text { Ali Y, et al., } \\
2009^{1}\end{array}$ & $31, M$ & $\begin{array}{l}\text { Bilateral } \\
\text { cerebellopontine } \\
\text { angles and the } \\
\text { thoracic spine at } \\
\text { the T5-T6 level }\end{array}$ & $\begin{array}{l}\text { Meningeal } \\
\text { melanocytoma }\end{array}$ & $\begin{array}{l}\text { Gross-total } \\
\text { resection of } \\
\text { the thoracic } \\
\text { lesion }\end{array}$ & None & $\begin{array}{l}\text { Follow up at a } \\
\text { few weeks after } \\
\text { operation: a rapidly } \\
\text { progressive coma, } \\
\text { with signs of } \\
\text { brainstem } \\
\text { compression and } \\
\text { hemodynamic } \\
\text { instability, ultimately } \\
\text { leading to his death. }\end{array}$ \\
\hline $\begin{array}{l}\text { Lee } \mathrm{CH} \text {, et al., } \\
2010^{9}\end{array}$ & $39, M$ & $\begin{array}{l}\text { Spreading from } \\
\text { the level of } C 1 \text { to } \\
\text { the level of } C 6\end{array}$ & $\begin{array}{l}\text { Malignant } \\
\text { melanoma }\end{array}$ & $\begin{array}{l}\text { Gross-total } \\
\text { removal }\end{array}$ & $\begin{array}{l}\text { Local radiation } \\
\text { therapy and } \\
\text { adjuvant } \\
\text { chemotherapy } \\
\text { were given. }\end{array}$ & $\begin{array}{l}\text { Follow up at } 17 \\
\text { months after } \\
\text { operation: no } \\
\text { recurrence on MRI }\end{array}$ \\
\hline $\begin{array}{l}\text { Current } \\
\text { report }\end{array}$ & $24, M$ & $\begin{array}{l}\text { Cervical and } \\
\text { upper thoracic } \\
\text { spine }\end{array}$ & $\begin{array}{l}\text { Intermediate- } \\
\text { grade } \\
\text { melanocytoma }\end{array}$ & $\begin{array}{l}\text { Gross-total } \\
\text { removal of } \\
\text { the duty } \\
\text { lesion }\end{array}$ & $\begin{array}{l}\text { Second surgery } \\
\text { for the other } \\
\text { masses but the } \\
\text { patient did not } \\
\text { accept further } \\
\text { treatment. }\end{array}$ & $\begin{array}{l}\text { Follow up at } 2 \text { weeks } \\
\text { after operation: the } \\
\text { left lower-extremity } \\
\text { strength and the } \\
\text { sensibility below } \\
\text { the level of T-7 were } \\
\text { markedly improved. }\end{array}$ \\
\hline
\end{tabular}



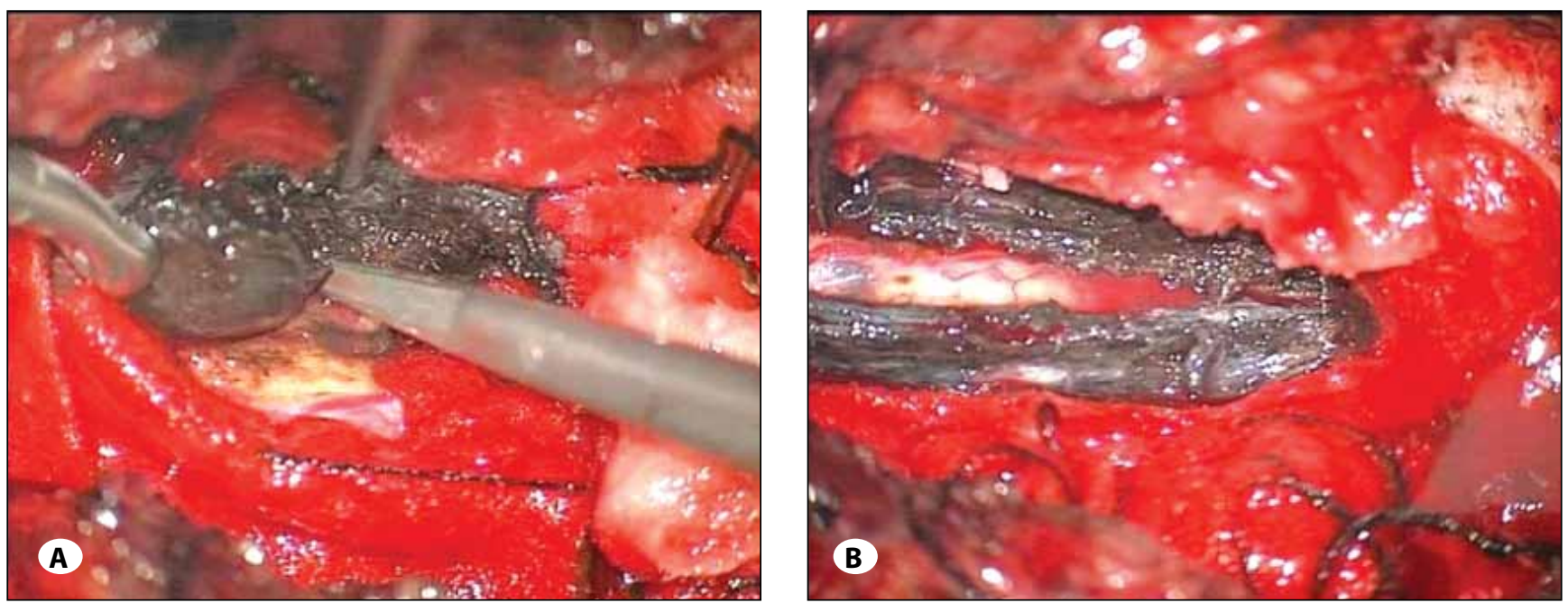

Figure 3: Intraoperative photographs showing the dura-based dark brown lesion compressing the edematous spinal cord (A), and the associated diffuse leptomeningeal hyperpigmentation (B).
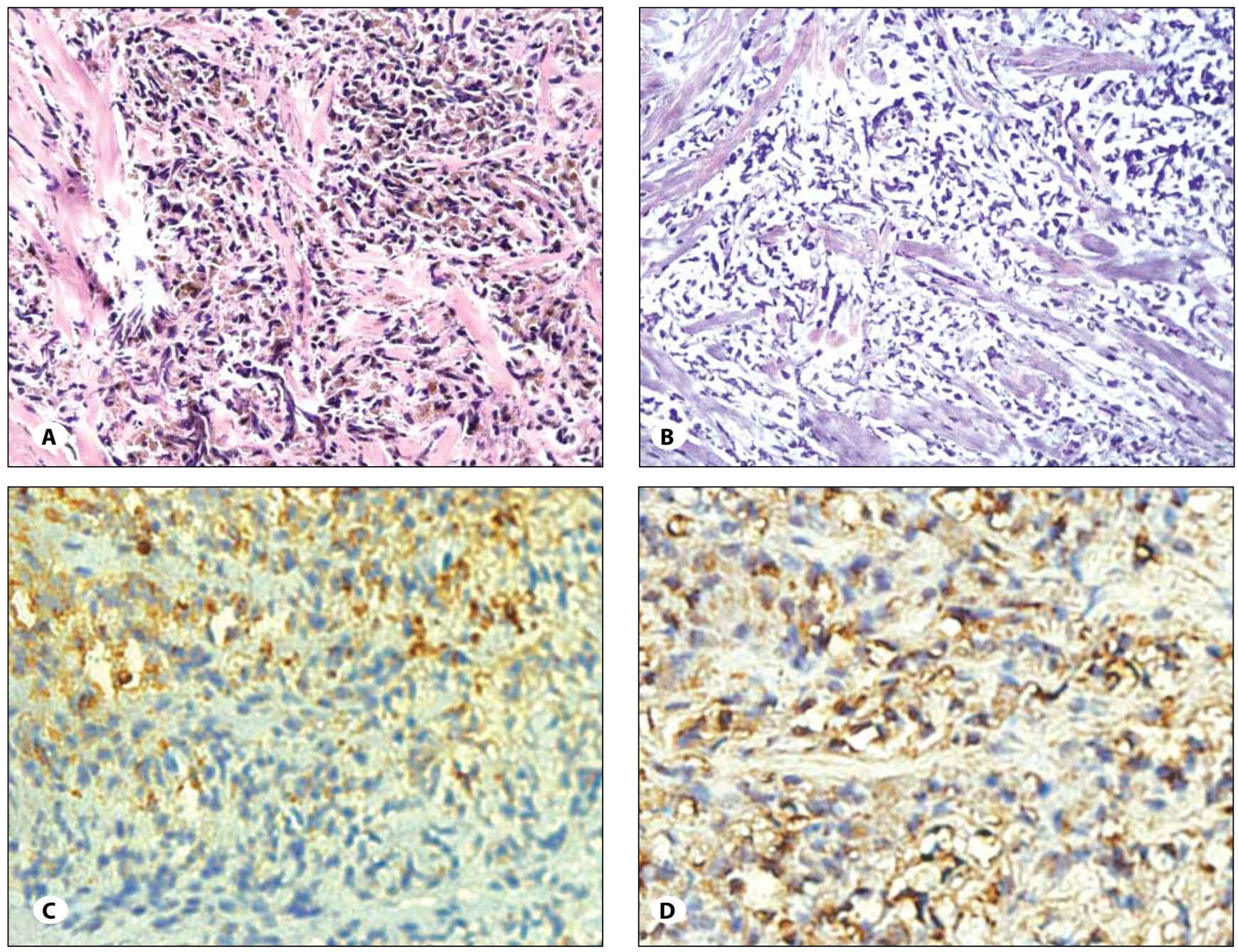

Figure 4: Histology of the PSM. (A) HE stain showing a moderately cell-dense collection of spindle cells with heavily pigmented cytoplasm, mainly arranged in a epithelioid and syncytial pattern. (B) Subjected to hydrogen peroxide bleaching showing the uniform and oval nuclei with small nucleoli. (C) HMB-45 immunopositivity of the tumor cells. (D) S100 immunopositivity of the tumor cells. A, $B, C, D \times 400$. 
CNS melanoma demonstrates positivity for vimentin, S100 protein, and HMB- 45, whereas a negative immunoreaction to epithelial membrane antigen, cytokeratin, neuron-specific enolase, and Leu-7 is usually observed. It remains a diagnostic challenge to distinguish between a well-differentiated, intermediate-grade melanocytic lesion, and malignant melanoma. A detailed description of the histopathological criteria for distinguishing among the wide spectrum of melanocytic lesions was provided by Navas et al.(10) and modified by Brat and Quatresooz $(2,11)$.

Because the biological behavior of PSM is variable, complete resection is advised when possible. Adjuvant radiation therapy and Gamma Knife radiosurgery have been shown to control tumor growth and improve outcome following partial resection $(1,12)$. Ali et al. reported a case study of a 31-year-old patient presenting with a multifocal meningeal melanocytoma simultaneously affecting both cerebellopontine angles and the thoracic spinal cord, and exhibiting a remarkably aggressive clinical course and a poor prognosis (1). In this case study, we introduce a new entity, multiple intermediate-grade melanocytoma, which similarly appears to portend a poor prognosis. Therefore, careful monitoring of patients diagnosed with PSM is strongly advised, particularly for cases exhibiting multiple lesions.

\section{REFERENCES}

1. Ali $Y$, Rahme R, Moussa R, Abadjian G, Menassa-Moussa L, Samaha E: Multifocal meningeal melanocytoma: A new pathological entity or the result of leptomeningeal seeding? Case report. J Neurosurg 111: 488-491, 2009

2. Brat DJ, Giannini C, Scheithauer BW, Burger PC: Primary melanocytic neoplasms of the central nervous system. Am J Surg Pathol 23: 745-754, 1999
3. El-Khashab M, Koral K, Bowers DC, Johnson-Welch S, Swift $D$, Nejat F: Intermediate grade meningeal melanocytoma of cervical spine. Childs Nerv Syst 25: 407-410, 2009

4. Foit NA, Neidert MC, Woernle CM, Rushing EJ, Krayenbühl N: Bifocal extra-and intradural melanocytoma of the spine: Case report and literature review. Eur Spine J 22: 521-525, 2013

5. Farrokh D, Fransen P, Faverly D: MR findings of a primary intramedullary malignant melanoma: Case report and literature review. AJNR Am J Neuroradiol 22: 1864-1866, 2001

6. Hirano A, Carton CA: Primary malignant melanoma of the spinal cord. J Neurosurg 17: 935-944, 1960

7. Horn EM, Nakaji P, Coons SW, Dickman CA: Surgical treatment for intramedullary spinal cord melanocytomas. J Neurosurg Spine 9:48-54, 2008

8. Hayward R: Malignant melanoma and the central nervous system. A guide for classification based on the clinical findings. J Neurol Neurosurg Psychiatry 39: 526-530, 1976

9. Lee $\mathrm{CH}$, Moon $\mathrm{KY}$, Chung $\mathrm{CK}$, Kim HJ, Chang $\mathrm{KH}$, Park $\mathrm{SH}$, Jahng TA: Primary intradural extramedullary melanoma of the cervical spinal cord: Case report. Spine 35: 303-307, 2010

10. Navas M, Pascual JM, Fraga J, Pedrosa M, Shakur S, Carrasco R, Martínez P, Manzanares R, de Sola RG: Intracranial intermediate-grade meningeal melanocytoma with increased cellular proliferative index: An illustrative case associated with a nevus of Ota. J Neurooncol 95: 105-115, 2009

11. Quatresooz P, Piérard-Franchimont C, Piérard GE: Highlighting the immunohistochemical profile of melanocytomas: Review. Oncol Rep 19: 1367-1372, 2008

12. Rades D, Tatagiba M, Brandis A, Dubben HH, Karstens JH: The value of radiotherapy in treatment of meningeal melanocytoma. Strahlenther Onkol 178:336-342, 2002

13. Yu J, Zhao D, Chen S, Zhang J, Xu J: Primary melanoma of the cervical spine with cerebral metastases: Case report and review of the literature. J Int Med Res 40:1207-1215, 2012 